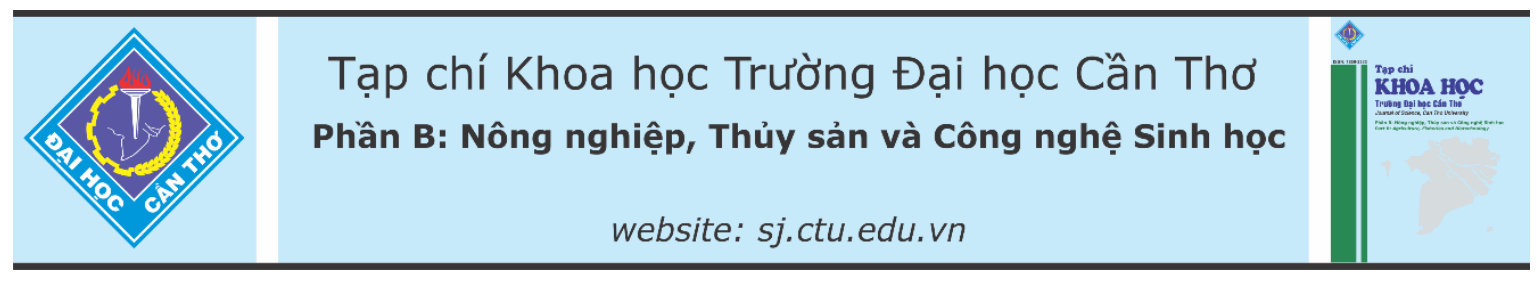

DOI:10.22144/ctu.jvn.2021.095

\title{
ĐỀ XUẤT MÔ HİNH NÔNG NGHIỆP ĐÔ THỊ THEO HƯỚNG BỀn VŨ̃NG TẠI THÀNH PHỐ SÓC TRĂNG, TỈNH SÓC TRĂNG
}

\author{
Nguyễn Văn Nhiều Em* \\ Khoa Khoa học Xã hội và Nhân văn, Truờng Đại học Cần Tho \\ *Nguoòi chịu trách nhiệm về bài viết: Nguyễn Văn Nhiều Em (email: nvnem@ctu.edu.vn)
}

\section{Thông tin chung:}

Ngày nhận bài: 21/12/2020

Ngày nhận bài sủa: 07/01/2021

Ngày duyệt đăng: 25/06/2021

\section{Title:}

The proposed models of sustainable urban agriculture in Soc Trang city, Soc Trang province

\section{Tù khóa:}

Nông nghiẹp đô thị, mô hình, tiêu chí, tiềm năng phát triển

\section{Keywords:}

Development potential, model, indicator, urban agriculture

\begin{abstract}
The research was carried out to propose urban agricultural models with high efficiency, sustainability, and harmony between socio-economic values and environment. Research methods include secondary data collection, 51 Key Informant Panels (KIP) internal area of urban agriculture sector, 10 Participatory Rural Appraisal discussions, and land evaluation, 182 household surveys in Soc Trang city. The results showed that the agricultural system in the Soc Trang city is relatively diverse in terms of farming model and farming scale. The agricultural structure has 3 fields of crop cultivation, animal husbandry, and aquaculture fisheries. Moreover, the researchersidentified 23 important indicators for the planning and development of urban agriculture in Soc Trang city towards sustainability. In addition, this study has also proposed 6 potential development models in urban and suburban urban areas, including (1) ornamental plantss, (2) abalone mushroom cultivation, (3) hydroponic vegetables (inner area models); (4) high-quality rice, (5) safe vegetables and (6) dairy cow - biogas silage (peri-urban area).
\end{abstract}

\section{TÓM TÁT}

Nghiên cứu được thực hiện nhằm đề xuất các mô hình nông nghiệp đô thị mang hiệu quả cao, bền vũng, hài hòa giữa giá trị kinh tể-xã hội và môi truờng. Phuoong pháp nghiên cứu bao gồm thu thập số liệu thú cấp, phỏng vấn 51 chuyên gia (KIP) về lĩnh vục nông nghiệp đô thị, 10 cuộc thảo luận PRA và đánh giá thich nghi đất đai, phỏng vấn 182 nông hộ tại Thành phố Sóc Trăng. Kết quả nghiên cưu cho thấy hệ thống nông nghiệp đô thị ở Thành phố Sóc Trăng tuơng đối đa dạng về mô hình canh tác và quy mô canh tác. Co cấu nông nghiệp có đủ 3 lĩnh vục trồng trọt, chăn nuôi và thủy sản. Nghiên cúu đã xác định được 23 chi tiêu quan trọng cho quy hoạch và phát triển nông nghiệp đô thị tại thành phố Sóc Trăng theo huoóng bền vũng. Bên cạh đó, nghiên cứu cũng đã đề xuất được 6 mô hình tiềm năng phát triển ở khu vực đô thị Thành phố Sóc Trăng, cu thể cho vùng nọi ô có: (1) hoa kiểng, (2) nấm bào ngu, (3) rau thủy canh; cho vùng ven đô có: (4) lúa chất lượng cao, (5) rau an toàn và (6) bò sũa-hầm ủ Biogas (vùng ven đô).

\section{GIỚI THIỆ}

Nông nghiệp đô thị là ngành sản xuất ở trung tâm, ngoại ô và vùng lân cận đô thị, có chức năng trồng trọt, chăn nuôi, chế biến và phân phối các loại thực phẩm, lương thực và các sản phẩm khác, sử dụng các nguồn lực tự nhiên và nhân văn, các sản phẩm cùng các dịch vụ ở đô thị và vùng lân cận đô 
thị để cung cấp trở lại cho đô thị các sản phẩm và dịch vụ cao cấp. Nông nghiệp đô thị bao gồm nông nghiệp nội thị và nông nghiệp ngoại thị với các hoạt động chủ yếu là trồng trọt, chăn nuôi, lâm nghiệp và thủy sản (FAO, 1996; UNDP, 1999; Mougeot, 2002). Đây là xu hướng phát triển mới và quan trọng trong quá trình phát triển nông nghiệp và phát triển đô thị xanh của đất nước (Đào Lan Phương, 2012; Mardy et al., 2013). Sóc Trăng là thành phố có nhiều khu vực nông nghiệp nông thôn đã và đang chuyển thành khu vực nông nghiệp đô thị trong một thời gian ngắn (Sở Nông nghiệp và Phát triển Nông thôn tỉnh Sóc Trăng, 2010).

Với tốc độ đô thị hóa ngày càng cao, diện tích đất nông nghiệp ngày càng thu hẹp tại các khu vực đô thị và ven đô, nhu cầu tăng giá trị sản xuất, nâng cao thu nhập, tạo công ăn việc làm, cung ứng nông sản hàng hóa chất lượng cao, an toàn, vệ sinh thực phẩm,... ngày càng cao (Zezza $\&$ Tasciotti, 2010). Bên cạnh đó, do mật độ dân cư cao ở khu vực đô thị, yêu cầu về một nền nông nghiệp xanh, sạch, an toàn và thân thiện với môi trường cũng ngày càng cấp bách (Bulter and Maronek, 2002). Vì vậy, việc nghiên cứu xác định mô hình nông nghiệp đô thị và quy hoạch vùng sản xuất hiệu quả cao, bền vững, hài hòa giữa giá trị kinh tế-xã hội- môi trường đô thị theo chiến lược phát triển của tỉnh (Sở Nông nghiệp Phát triển Nông thôn tỉnh Sóc Trăng, 2010), kêt hợp với đánh giá chuyên gia và nhu cầu người dân là rât cần thiết.

\section{PHƯƠNG PHÁP NGHIÊN CÚU}

\subsection{Phương pháp phỏng vấn chuyên gia - KIP}

Phỏng vấn bằng câu hỏi mở đối với 51 chuyên gia về lĩnh vực nông nghiệp và nông nghiệp đô thị (các chuyên gia trong lĩnh vực khoa học, Lãnh đạo địa phương tại các sở nông nghiệp và phát triển nông thôn, UBND các phường, hội nông dân,...) xây dựng và đánh giá các tiêu chí về mô hình nông nghiệp đô thị trên cơ sở đánh giá nhiều lựa chọn và xây dựng các trọng số cho các tiêu chí của 3 lĩnh vực: môi trường, xã hội và kinh tế thông qua việc đánh giá của chuyên gia trong lĩnh vực nông nghiệp đô thị.

\subsection{Phương pháp thảo luận nhóm và phỏng vấn nông hộ}

Khảo sát ở nông hộ, thu thập các thông tin chi tiết liên quan đến các mô hình sản xuất nông nghiệp hiện hữu theo biểu điều tra. Nghiên cứu đã thực hiện phỏng vấn 182 nông hộ tại thành phố Sóc Trăng (TPST). Số liệu được phân tích bằng phương pháp thống kê mô tả bao gồm thống kê tần suất cho câu hỏi có nhiều sự lựa chọn (multiple response).

Nghiên cứu đã thực hiện 10 cuộc phỏng vấn ở 5 phường được chọn nghiên cứu và tại các sở ngành như Sở Nông nghiệp và Phát triển Nông thôn, Sở Kế hoạch và Đầu tư, Sở Tài nguyên và Môi trường, Sở Khoa học và Công nghệ, Phòng Kinh tế, Hội Nông dân. Thành phần tham gia là lãnh đạo địa phương, lãnh đạo các cơ quan ban ngành và nông dân có kinh nghiệm trong sản xuất nông nghiệp tại TPST.

\subsection{Phương pháp phân vùng thích nghi cho các mô hình nông nghiệp đô thị}

Sử dụng phương pháp đánh giá và phân vùng thích nghi của FAO (1976), phân cấp các yếu tố thích nghi cho các mô hình nông nghiệp đô thị bao gồm các bước:

- Xác định yếu tố chẩn đoán: Chất lượng nước: phân ra các cấp độ mặn: $0-<2 \%$ oo; $2 \%$ oo; $>2 \%$ oo$3 \%$; Cao độ của đất: phân ra các cấp độ từ $0-<0,63$; $0,63-<1,09 ; 1,09-1,5$ và $>1,5 \mathrm{~m}$; Loại đất: đất phù sađất phù sa phát triển- đất phèn hoạt động- cát, đất bồi (đất nhiễm mặn); Khả năng mưa: $>1.000 \mathrm{~mm}$; 500-1.000mm; <500mm; 0mm

- Xây dựng các bản đồ đơn tính

- Phân cấp thích nghi cho các yếu tố chẩn đoán

- Xây dựng các bản đồ đơn vị đất đai

Đánh giá và phân vùng thích nghi các mô hình nông nghiệp đô thị: dựa vào bảng tổng hợp đơn vị đất đai và các yếu tố chẩn đoán đã được chọn ra cho mô hình sản xuất để thành lập bảng phân cấp thích nghi cho từng đơn vị đất đai; sử dụng bảng tính "Excel" nhập tất cả các yếu tố chẩn đoán cho từng cơ cấu sử dụng đất cho tất cả các đơn vị đất đai; dựa vào bảng phân cấp yếu tố thích nghi để tính được thích nghi đơn tính của đơn vị bản đồ đất đai; khi tính được cấp thích nghi đơn tính của từng đơn vị bản đồ đất đai, thì áp dụng phương pháp giới hạn yếu tố thích nghi tổng hợp cho đơn vị bản đồ đất đai.

\section{KẾT QUẢ VÀ THẢO LUẬN}

\subsection{Thực trạng các mô hình canh tác nông nghiệp của nông hộ tại TPST}

Kết quả khảo sát thực trạng các mô hình nông nghiệp từ 182 phiếu phỏng vấn nông hộ tại TPST cho thấy mô hình liên quan đến hoạt động trồng trọt chiếm $83 \%$ số hộ thực hiện, mô hình chăn nuôi chiếm $35,7 \%$ và nuôi trồng thủy sản chiếm $7,1 \%$ (Hình 1). 


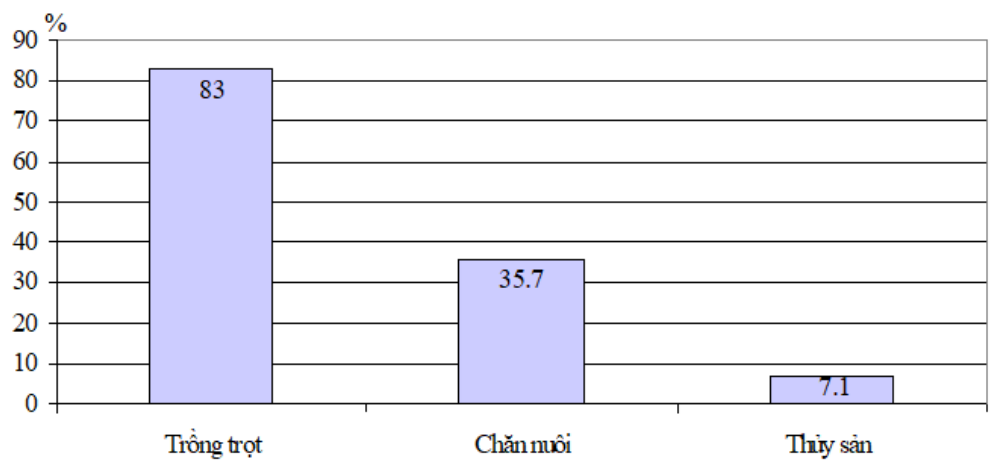

Hình 1. Các mô hình canh tác của các nông hộ tại TPST

Kết quả khảo sát cho thấy các loại cây trồng chủ yếu được các nông hộ canh tác phổ biến trong mô hình (Hình 2a) rất đa dạng. Trong đó, lúa là loại cây trồng được các nông hộ canh tác nhiều nhất với tỷ lệ $65,93 \%$ số hộ tham gia khảo sát, cây màu chiếm tỷ lệ $36,26 \%$ vì canh tác hoa màu cũng là ngành nghề truyền thống của đồng bào dân tộc Khmer TPST,

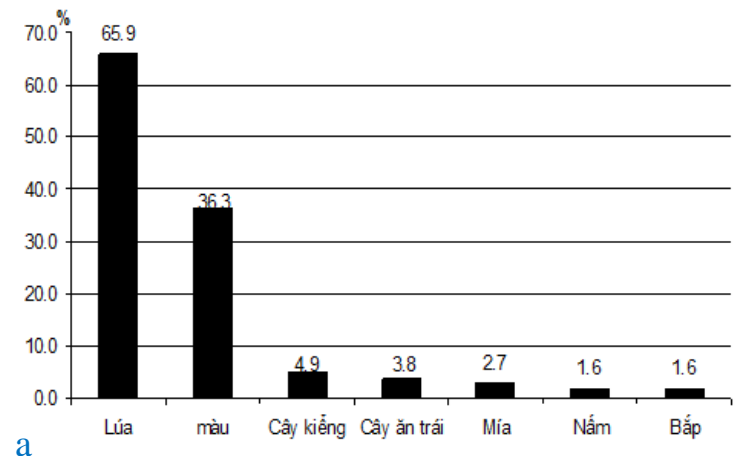

các loại cây màu được trồng chủ yếu là: ớt, hẹ, rau thơm, các loại rau cải, bầu, bí, cây họ đậu, khoai lang, khoai ngọt. Các loại cây trồng khác như cây kiểng $(4,95 \%)$, cây ăn trái $(3,85 \%)$, cây mía $(2,75 \%)$ và tỷ lệ rất nhỏ các hộ trồng bắp, nấm bào ngư và nấm linh chi (Hình 2b).

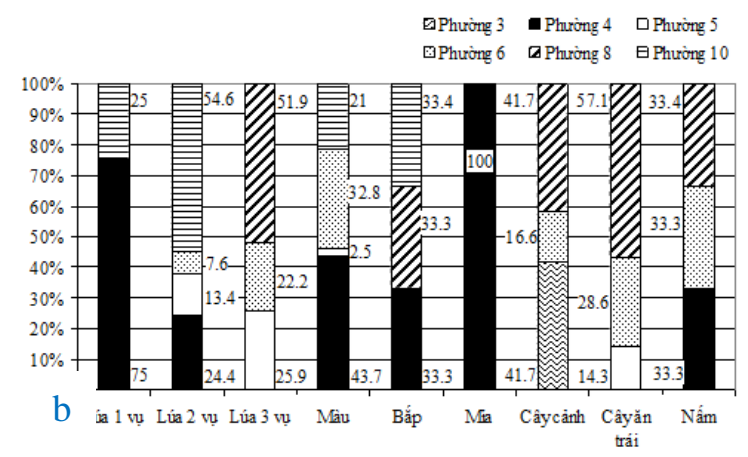

Hình 2. Các loại cây trồng chủ yếu trong mô hình (a) và sự phân bố các loại cây trồng theo khu vực (b) tại TPST

Sự phân bố các loại cây trồng theo từng phường nghiên cứu tại TPST (Hình $2 \mathrm{~b}$ ) cho thấy mô hình nẩm được trồng ở phường 4 , phường 6 và phường 8 . Cây ăn trái được trồng nhiều nhất ở phường 8 với tỷ lệ $57,1 \%$, cây cảnh được trồng nhiều nhất ở phường 3 và phường 8 với đồng tỷ lệ $41,7 \%$. Cây mía chỉ có ở phường 4 . Cây bắp được trồng ở phường 4 , phường 8 và phường 10 . Cây màu được trồng nhiều nhất ở phường 4 với tỷ lệ $43,7 \%$. Lúa có mặt ở tất cả các phường nghiên cứu, trong đó lúa 3 vụ được trồng nhiều nhất ở phường 8 với tỷ lệ $51,9 \%$, lúa 2 vụ được trồng nhiều nhất ở phường 10 với tỷ lệ
$54,6 \%$ và lúa 1 vụ được trồng nhiều nhất ở phường 4 với tỷ lệ $75 \%$ trong tổng số hộ được khảo sát.

Kết quả khảo sát các loại gia súc gia cầm chủ yếu trong các mô hình chăn nuôi ở TPST (Hình $3 \mathrm{a}$ ) cho thấy mô hình chăn nuôi heo và bò là hai loại gia súc chiếm phần lớn trong tổng số hộ tham gia mô hình được khảo sát. Trong đó, heo chiếm 46,67\% trong 182 hộ tham gia khảo sát trên tổng số câu trả lời được ghi nhận trong khảo sát, bò chiếm 34,67\% các loại gia cầm khác chiếm $5,33 \%$ bao gồm gia cầm và thỏ, còn lại 13,33 \% hộ được khảo sát không chăn nuôi (Hình 3a). 


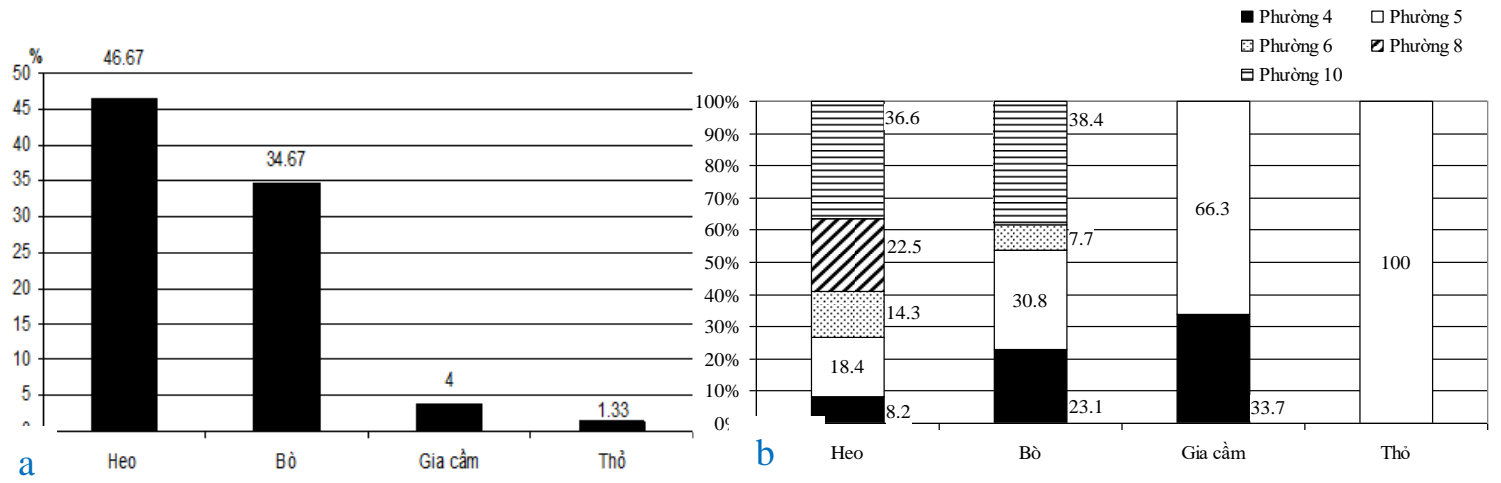

Hình 3. Các loại vật nuôi chủ yếu trong mô hình chăn nuôi (a) và sự phân bố các loại vật nuôi theo khu vục (b) tại TPST

Hình $3 b$ thể hiện sự phân bố các loại vật nuôi theo từng phường được khảo sát tại TPST. Các loại vật nuôi được phân bố không đồng đều ở từng khu vực của TPST. Mô hình chăn nuôi heo được phân bố ở hầu hết các phường trong TPST. Trong đó, phường 10 với tỷ lệ nuôi cao nhất $(36,6 \%)$, phường 4 có tỷ lệ nuôi thấp nhất $(8,2 \%)$. Mô hình chăn nuôi bò cũng phân bố ở hầu hết các phường, phường có tỷ lệ nuôi bò cao nhất với $38,4 \%$ là phường 8 và phường 10 , thấp nhất là phường 6 chỉ có $7,7 \%$. Chăn nuôi gia cầm được tập trung nuôi ở phường 5 với $66,3 \%$ và phường 4 với $33,7 \%$. Loại vật nuôi khá mới đối với mô hình chăn nuôi của TPST đó là mô hình nuôi thỏ và mới được nuôi thử nghiệm ở phường 5 (Hình $3 b$ ).

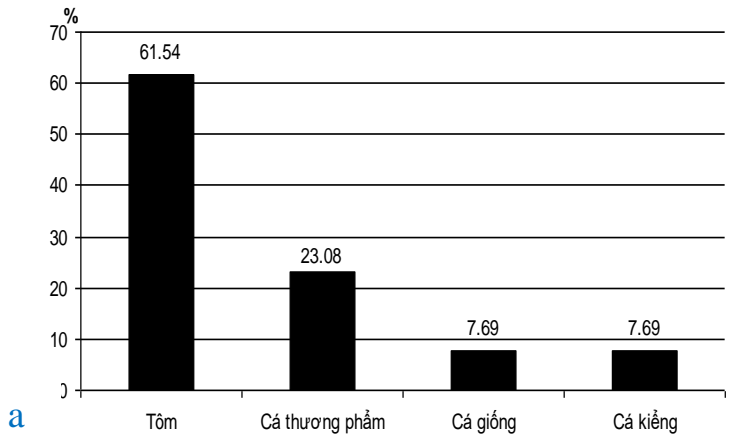

Hình 4 thể hiện tỷ lệ các loại thủy sản chủ yếu trong mô hình nuôi thủy sản ở TPST tính trên số hộ điều tra. Trong số đó, tôm chiếm tỷ lệ cao nhất với $61,54 \%$, cá kiểng và các giống là loại thủy sản mới được nông hộ tiến hành nuôi thử ngiệm tại TPST chiếm 7,69\%. Kết quả nghiên cứu cho thấy thủy sản không phải là thế mạnh của nông nghiệp đô thị TPST. Hình $4 \mathrm{~b}$ chỉ ra rằng phường 4 , phường 5 và phường 8 có sự xuất hiện của các mô hình nuôi thủy sản. Cá giống và cá cảnh chỉ được nuôi ở phường 8 , tôm chỉ được nuôi ở phường 4 . Cá thương phẩm được nuôi ở phường 5 với $25 \%$ và phường 8 với $75 \%$.

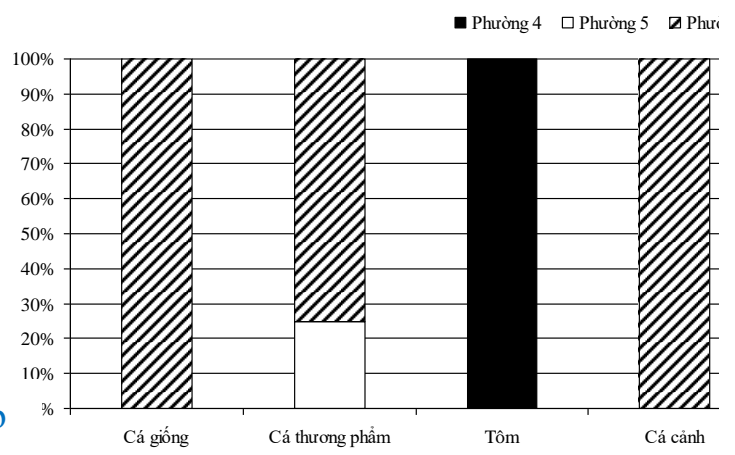

Hình 4. Các loại thủy sản chủ yếu trong mô hình nông nghiệp đô thị (a) và sự phân bố của chúng tại các Phường (b) của TPST

\subsection{Xây dụng bộ tiêu chí lựa chọn mô hình nông nghiệp đô thị TPST}

Trên cơ sở phân tích thực trạng và đánh giá chuyên gia trong việc xây dựng mô hình nông nghiệp đô thị kết hợp với hội thảo đánh giá và nhận định các vấn đề liên quan,... Bộ tiêu chí được đề xuất với 23 tiêu chí cho 3 lĩnh vực: môi trường, xã hội và kinh tế, để lựa chọn và xây dựng mô hình nông nghiệp đô thị trên cơ sở phát triển hiệu quả về kinh tế, bền vững về môi trường và đáp ứng nhu cầu xã hội.

\subsubsection{Tiêu chí về môi trường}

1.Tiết kiệm năng lượng (sử dụng các nguồn năng lượng tự nhiên như gió, ánh nắng mặt trời, hệ thống dẫn nước khép kín). 
2.Góp phần bảo tồn, phục tráng và phát triển các giống vật nuôi, cây trồng đặc trưng của địa phương.

3.Giảm mức độ sử dụng hóa chất (thuốc trừ sâu, thuốc diệt cỏ,) và phân bón.

4.Góp phần điều hòa nhiệt độ, giảm sức nóng trong đô thị.

5.Sử dụng các vật liệu tự nhiên, rác thải không độc, thân thiện với môi trường, dễ tái chế, ít tốn kém, phù hợp với nông nghiệp ở đô thị (tận dụng rác thải hữu cơ đô thị cho sản xuất nông nghiệp như: sản xuất phân trộn từ rác thải đô thị, thuốc trừ sâu hữu cơ, thức ăn cho vật nuôi).
6.Tăng cường tính đa dạng trong sử dụng đất, cải thiện độ phì nhiêu của đất và phù hợp với điều kiện đất đai ở đô thị.

7.Tận dụng sử dụng nước thải ở đô thị (chứa nhiều chất dinh dưỡng, không tốn kém) để phục vụ quá trình sản xuất nông nghiệp ở đô thị, từ đó giúp cải thiện chất lượng nguồn nước.

8.Sử dụng hiệu quả nguồn chất thải từ mô hình sản xuất cho các hoạt động tiết kiệm chi phí và tăng thu nhập cho nông hộ.

Bảng 1. Kết quả đánh giá trọng số của 8 tiêu chí về môi trường

\begin{tabular}{|c|c|c|c|c|c|c|c|c|c|c|}
\hline \multirow{2}{*}{ Hạng mục } & \multirow{2}{*}{ Cở mẫu (n) } & \multicolumn{9}{|c|}{ Tiêu chí môi trường (A) } \\
\hline & & Tổng (A) & 1 & 2 & 3 & 4 & 5 & 6 & 7 & 8 \\
\hline Điểm trên 10 & 51 & 53,9 & 7,4 & $\overline{7,0}$ & 8,9 & 7,8 & 7,9 & 7,5 & 7,58 & $\overline{8,2}$ \\
\hline Hệ số quy đổi (\%) & 51 & 29,1 & 4,0 & 3,8 & 4,8 & 4,2 & 4,3 & 4,0 & 4,04 & 4,4 \\
\hline
\end{tabular}

\subsubsection{Tiêu chí về Xã họi}

9. Đáp ứng nhu cầu của địa phương về sản phẩm sạch. Giải quyết vấn đề thiếu hụt thực phẩm phải nhập khẩu hoặc sản phẩm phải vận chuyển từ nông thôn ra thành thị (tốn kém và phải bảo quản), cung cấp nguồn thức ăn tươi sống, có đầy đủ chất dinh dưỡng,

10. Đảm bảo chất lượng, an toàn cho người tiêu dùng, giúp cải thiện sức khỏe cho cộng đồng địa phương.

11. Giúp ổn định và nâng cao chất lượng cuộc sống. Tạo ra nhiều cơ hội việc làm mới, góp phần

Bảng 2. Kết quả đánh giá trọng số của 6 tiêu chí về văn hoá - xã hội

\begin{tabular}{lccccccr}
\hline \multirow{2}{*}{ Hạng mục } & \multirow{2}{*}{ Cõ̃ mẫu (n) } & \multicolumn{2}{l}{ Tiêu chí Văn hóa - Xã hội (B) } & & & & \\
\cline { 2 - 8 } & & Tồng (B) & $\mathbf{9}$ & $\mathbf{1 0}$ & $\mathbf{1 1}$ & $\mathbf{1 2}$ & $\mathbf{1 3}$ \\
\hline Điểm trên 10 & 51 & 49,5 & 8,8 & 8,5 & 7,8 & 7,8 & 8,5 \\
Hệ số quy đổi (\%) & 51 & 26,8 & 4,8 & 4,6 & 4,2 & 4,2 & 4,6 \\
\hline
\end{tabular}

\subsubsection{Tiêu chí về Kinh tế}

14. Tạo sự liên kết thị trường (giữa nông dân, doanh nghiệp, người tiêu dùng, các tổ chức đoàn thể địa phương, nhà khoa học).

15.Tăng thêm nguồn thu nhập mới cho cộng đồng ở đô thị.

16.Tận dụng đất ở đô thị một cách hiệu quả để tối đa hóa diện tích sử dụng cho trồng trọt/chăn nuôi.

17.Tiết kiệm chi phí sản xuất: chi phí vận chuyển, chi phí bảo quản sản phẩm từ cây trồng, vật nuôi hoặc các loại chi phí khác có liên quan trong giải quyết vấn đề việc làm - thất nghiệp ở đô thị, tạo công ăn việc làm cho người nghèo; nâng cao thu nhập người dân, giảm nghèo, tạo điều kiện để người dân có thể chi tiêu nhiều hơn cho giáo dục và y tế.

12. Góp phần quản lý hiệu quả tài nguyên, tận dụng các chất thải, giảm ô nhiễm, cải thiện môi trường sống, tăng cường không gian xanh, tạo vẻ mỹ quan ở đô thị từ đó nâng cao chất lượng môi trường sống của cộng đồng dân cư.

13. Thúc đẩy xây dựng cộng đồng. quá trình thực hành nông nghiệp (chi phí phân bón, thức ăn, nước tưới tiêu,...).

18.Giống cây trồng, vật nuôi có năng suất và phẩm chất tốt (khả năng thích nghi và chống chịu tốt với điều kiện ngoại cảnh, dịch bệnh, thời gian nuôi trồng được rút ngắn, giúp tăng cường số vụ mùa có thể thu hoạch được trong một năm từ đó nâng cao hiệu quả kinh tế).

19.Cung cấp các sản phẩm nông nghiệp chất lượng cho địa phương, các khu vực khác trong cả nước và mở rộng thị trường tiến đến xuất khẩu các sản phẩm nông nghiệp đô thị chất lượng cao sang các nước khác trên thế giới. 
20. Xây dựng không gian xanh thư giãn ở đô thị kết hợp với du lịch sinh thái phục vụ cho người dân trong nước và du khách.

21. Phù hợp với nguồn lực của cư dân đô thị.
22. Mô hình dễ dàng chuyển giao và nhân rộng sản xuất.

23. Áp dụng công nghệ cao, cơ giới hóa góp phần thúc đẩy phát triển kinh tế địa phương.

Bảng 3. Kết quả đánh giá trọng số của 10 tiêu chí về kinh tế của nhóm chuyên gia và người dân

\begin{tabular}{|c|c|}
\hline Hạng mục & Cõ̃ mẫu (n) \\
\hline Điểm trên 10 & 51 \\
\hline Hệ số quy đổi (\%) & 51 \\
\hline
\end{tabular}

Theo kết quả đánh giá, có 6 mô hình nông nghiệp đô thị theo hướng bền vững được đề xuất dựa cơ sở định hướng chiến lược phát triển nông nghiệp đô thị TPST và 23 tiêu chí được xây dựng dựa trên ý kiến tham luận của chuyên gia và người dân trên địa bàn TPST (Hình 5).

Đối với vùng nội ô, hoa kiểng, nấm bào ngư và rau thủy canh là những loại cây trồng rất có tiềm năng phát triển trong bối cảnh nền nông nghiệp ngày càng phát triển hiện đại. Đây là 3 mô hình trồng thích hợp nhất trong vùng nội ô của TPST phát triển trong giai đoạn tới nhằm để xây dựng một nền nông nghiệp vừa có tính bền vững phù hợp với xu hướng phát triển vừa nâng cao thu nhập cho người dân.

Đối với vùng ven đô thành phố, các mô hình lúa chất lượng cao, rau an toàn và nuôi bò sữa- hầm ủ biogas là thích hợp với thực trạng hiện nay vì mô hình này mang lại hiệu quả kinh tế cao và các nông hộ khu vực ven đô có đủ điều kiện thuận lợi nhất về tự nhiên, nguồn nhân lực, thổ nhưỡng và có mức tác động đến môi trường tương đối thấp, đầu ra phù hợp và đáp ứng với nhu cầu thị trường trong việc sản xuất và tiêu thụ sản phẩm, đồng thời cung cấp cho vùng nội ô những sản phẩm đảm bảo chất lượng an toàn thực phẩm.

Đây là những mô hình nông nghiệp đô thị định hướng phát triển cho giai đoạn tiếp theo của nền nông nghiệp đô thị của TP Sóc Trăng. Tuy nhiên sẽ phải tùy vào tiềm lực kinh tế của mỗi nông hộ, quy mô diện tích đất canh tác mà nông hộ đang sở hữu, năng lực kinh nghiệm mà nông hộ đang có, điều kiện tự nhiên như thổ nhưỡng, khí hậu và truyền thống văn hóa ở tại mỗi khu vực mà có hình thức khuyến cáo thích hợp theo hướng canh tác mô hình nào cho phù hợp nhất với từng nông hộ.

Trên cơ sở định hướng chiến lược phát triển nông nghiệp đô thị TPST, các mô hình nông nghiệp được lựa chọn qua các tiêu chí đánh giá, phân tích thực trạng, đánh giá chuyên gia và đề xuất trên cơ sở phân vùng thích nghi cho hai vùng nội ô và ven đô của TPST. Tương ứng với từng vùng sẽ có những mô hình tiêu biểu dựa trên chỉ tiêu lựa chọn là có hiệu quả nhất trong số các mô hình cùng lĩnh vực và những mô hình có tiềm năng phát triển. Các mô hình sẽ được đánh giá, phân vùng thích nghi và xây dựng bản đồ quy hoạch thông qua các yếu tố tự nhiên cho các mô hình chịu ảnh hưởng trực tiếp với điều kiện tự nhiên là 2 mô hình: (4) lúa chất lượng cao và (5) rau an toàn. Các mô hình còn lại đối với vùng nội ô gồm có: (1) hoa kiểng; (2) nấm bào ngư và (3) rau thủy canh được quy hoạch phát triển như sau: mô hình (1) hoa kiểng phát triển ở các phường 1 , phường 2 , phường 3 , phường 5 và phường 6 vừa kinh doanh và vừa trang trí cho gia đình; mô hình nấm bào ngư tập trung phát triển ở phường 2 và phường 6 chủ yếu ở các hộ có diện tích đất trống từ $50 \mathrm{~m}^{2}$ trở lên; mô hình rau thủy canh phù hợp với diện tích nhỏ phát triển ở phường 1 và phường 3 vừa tận dụng cho tiêu dùng gia đình và vừa mang tính chất giải trí và trang trí. Đối với vùng ven đô thì mô hình (6) bò sữa- hầm ủ Biogas phát triển ở phường 3 và phường 5 , phường 8 và phường 9 . 


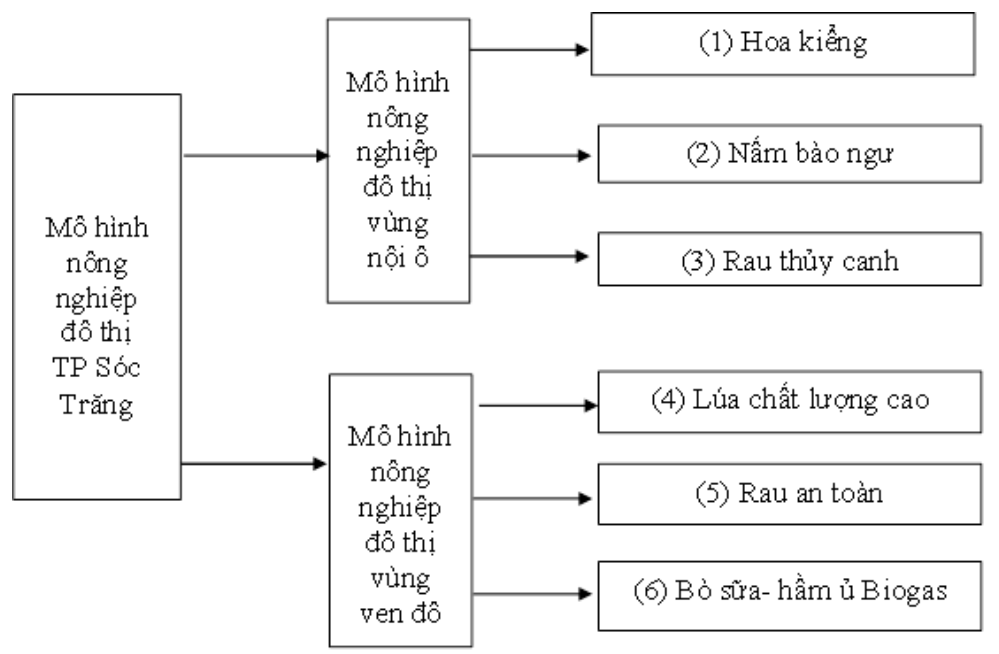

Hình 5. Mô hình nông nghiệp đô thị TPST

Trên cơ sở định hướng phát triển với mục tiêu quy hoạch và tổ chức lại sản xuất, phát triển bền vững mô hình, phân vùng thích cho các mô hình thích nghi tự nhiên theo các tiêu chí lựa chọn và phân cấp thích nghi cho mô hình. Kết hợp với quy hoạch và tổ chức lại sản xuất cho các mô hình sản xuất không chịu ảnh hưởng trực tiếp với điều kiện tự nhiên, đáp ứng yêu cầu phát triển theo định hướng chiến lược của TPST trong tương lai.

\subsection{Giải pháp phát triển bền vững mô hình nông nghiệp đô thị tại TPST}

Để phát triển bền vững mô hình nông nghiệp đô thị tại TPST, một số giải pháp thực hiện như sau:

\subsubsection{Quy hoạch vùng sản xuất}

Căn cứ vào tình hình môi trường, điều kiện tự nhiên về đất đai, độ sâu ngập, cao trình, chất lượng nước tiến hành thực hiện quy hoạch lựa chọn vùng thích nghi nhất.

Phân vùng quy hoạch, đảm bảo công tác quản lý hoạt động sản xuất và bảo đảm việc quản lý và kiểm soát tốt các vấn đề về môi trường thúc đẩy phát triển mô hình bền vững.

Xây dựng các dự án hỗ trợ các vùng sản xuất tập trung, đảm bảo công tác quản lý về các vấn đề kỹ thuật, điều phối theo nhu cầu thị trường, đáp ứng và giải quyết tốt vấn đề về xã hội.

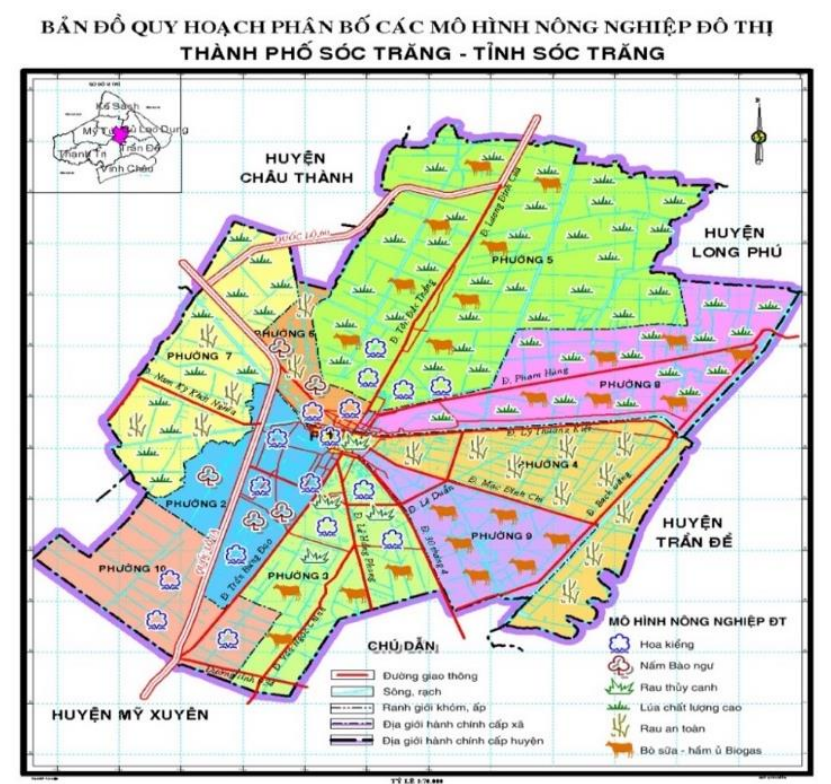

Hình 6. Bản đồ quy hoạch phân bố các mô hình nông nghiệp đô thị TPST 


\subsubsection{Tổ chức lại sản xuất}

Tổ chức lại các hoạt động sản xuất bằng các hình thức xây dựng các tổ hợp tác, hợp tác xã sản xuất cho các mô hình, đảm bảo chất lượng đáp ứng nhu cầu thị trường.

Tập huấn chuyển giao khoa học kỹ thuật đáp ứng yêu cầu phát triển từng mô hình, cân đối cung - cầu thị trường, từng bước hình thành các vùng sản xuất an toàn tại các vùng quy hoạch thích nghi.

\subsubsection{Hỗ trợ kỹ thuật}

Xây dựng liên kết mô hình sản xuất chất lượng cao phục vụ cho nhu cầu người tiêu dùng.

Khuyến khích và tạo điều kiện thuận lợi cho các thành phần kinh tế đầu tư thêm các hoạt động sản xuất chất lượng cao.

Định hướng chiến lược phát triển sản xuất mô hình theo hướng bền vững GAP, VietGAP, cung cấp nguồn sản phẩm chất lượng, an toàn cho người tiêu dùng.

Hướng dẫn các phương pháp xử lý ô nhiễm môi trường nhằm tăng hiệu quả trong hoạt động các mô hình.

Nâng cao trình độ, kỹ thuật cho người sản xuất, đảm bảo các lớp tập huấn thực sự đáp ứng nhu cầu người sản xuất.

Đào tạo, bồi dưỡng nâng cao năng lực cho cán bộ chuyên môn đủ sức kiểm tra, giám sát các mô hình trong các hoạt động sản xuất của nông hộ.

\subsubsection{Tăng cường liên kết}

Thành lập Tổ hợp tác để làm đầu mối ký kết hợp đồng liên kết với các doanh nghiệp tiêu thụ hoặc tiêu thụ sản phẩm thông qua các chợ đầu mối.

Xây dựng mối liên kết về vùng nguyên liệu, ký kết hợp đồng thu mua sản phẩm theo hướng sản xuất hiệu quả và ổn định lâu dài giữa thương lái và người sản xuất.

Tăng cường vai trò hoạt động của hợp tác xã, Hội Nông dân tỉnh trong việc tổ chức liên kết sản xuất các mô hình, làm cầu nối để các hộ sản xuất và thương lái thống nhất tham gia ký kết hợp đồng liên kết, đảm bảo tính khả thi cao trong hợp đồng, tạo sự ổn định trong quá trình sản xuất và tiêu thụ sản phẩm.

\subsubsection{Chính sách hỗ trọ̆}

Tăng cường các dịch vụ hỗ trợ vốn cho hoạt động sản xuất nông nghiệp đô thị với thời gian cho vay dài hơn, phù hợp với chu kỳ đầu tư và sản xuất của hộ.

Có chính sách hỗ trợ đối với các hộ khó khăn về vốn, có vị trí sản xuất không thuận lợi, kỹ thuật và kinh nghiệm sản xuất chưa tốt chuyển sang các mô hình sản xuất khác.

Có chính sách khuyến khích các sản xuất nhỏ lẻ có kỹ thuật, kinh nghiệm, vị trí sản xuất tốt thì cần phải tổ chức lại thành các tổ hợp tác hoặc hợp tác xã sản xuất có quy mô, đủ sức cạnh tranh để đăng ký sản xuất theo hướng bền vững.

Thực hiện nghiêm túc quy trình xử lý các chất gây ô nhiễm môi trường, xử lý nghiêm các vi phạm về chất lượng, mất an toàn vệ sinh thực phẩm.

\section{KẾT LUẬN}

Hoạt động sản xuất nông nghiệp đóng vai trò rất quan trọng trong nền kinh tế của nước ta. Theo đó, nông nghiệp đô thị ngày càng trở nên thiết yếu trong bối cảnh sự đô thị hóa ngày càng làm hạn hẹp diện tích đất canh tác. Kết quả nghiên cứu cho thấy hệ thống nông nghiệp đô thị ở TPST tương đối đa dạng về mô hình canh tác và quy mô canh tác. Cơ cấu nông nghiệp có đủ 3 lĩnh vực trồng trọt, chăn nuôi và thủy sản.

Có 6 mô hình tiềm năng phát triển ở khu vực đô thị TPST được đề xuất cho vùng nội ô và ven đô bao gồm: Vùng nội ô các mô hình (1) hoa kiểng, (2) nấm bào ngư, (3) rau thủy canh. Vùng ven đô bao gồm các mô hình: (4) lúa chất lượng cao, (5) rau an toàn và (6) bò sữa- hầm ủ Biogas.

Các mô hình được phân bố ở vùng nội ô bao gồm: (1) hoa kiểng phát triển ở các phường 1 , phường 2 , phường 3 , phường 5 , phường 6 và phường 10; (2) nấm bào ngư tập trung phát triển ở phường 2 và phường 6 ; (3) mô hình rau thủy canh phù hợp với diện tích nhỏ phát triển ở phường 1 và phường 3 vừa tận dụng cho tiêu dùng gia đình và vừa mang tính chất giải trí và trang trí. Đối với vùng ven đô thì mô hình (4) lúa chất lượng cao tập trung phát triển ở phường 5 , phường 7 , phường 8 ; mô hình (5) rau an toàn tập trung phát triển tại phường 4 , phường 6 và phường 7 ; (6) bò sữa- hầm ủ Biogas phát triển ở phường 3 và phường 5 , phường 8 và phường 9.

\section{TÀI LIỆU THAM KHẢO}

Butler, L. M., \& Maronek, D. M. (2002). Urban and agricultural communities: Opportunities for common ground. CAST Task Force Report, 138. https://www.cast-science.org/wp- 
content/uploads/2002/05/CAST_R138_Urbanand-Agriculture-Communities.pdf

Đào Lan Phương. (2012). Chính sách Tài chính đối với sự phát triển của nông nghiệp, nông dân và nông thôn Việt Nam, thực trạng và giải pháp. Tạp chí khoa học và công nghệ Lâm nghiệp, 1 , 125-135.

FAO. (1996). The state of food and agriculture 1996. ISBN 92-5-101858-9. FAO Agriculture Series no. 291. Rome (Italy).

Mardy, S., Nguyễn Phúc Thọ \& Chu Thị Kim Loan. (2013). Một số vấn đề lý luận, thực tiễn về phát triển nông nghiệp bền vững và những bài học cho phát triển nông nghiệp ở Campuchia. Tạp chí Khoa học và Phát triển, 11(3), 439-446.

Mougeot, L. J. (2000). Urban agriculture: Definition, presence, potentials and risks, and policy challenges. Cities feeding people series; rept. 31.
Sở Nông nghiệp Phát triển Nông thôn tỉnh Sóc Trăng. (2010). Báo cáo tổng hợp dự án rà soát, điều chỉnh, bổ sung quy hoạch phát triển Nông nghiệp - Nông thôn và quy hoạch phát triển các sản phẩm chủ lực ngành Nông nghiệp và Phát triển Nông thôn tỉnh Sóc Trăng đến năm 2015 và định hướng đến năm 2020.

UNDP. (1999). Human Development Report 1999: Globalization with a Human

Face. http://www.hdr.undp.org/en/content/huma n-development-report-1999

Zezza, A., \& Tasciotti, L. (2009). Urban Agriculture and Nutrition Empirical Evidence from a sample of Developing Countries, Food and Agriculture Organization.

http://www.fao.org/fileadmin/templates/FCIT/2425_Sept_ppt_presentations/TASCIOTTI_UA.pdf 